\title{
PRMT5 wt Allele
}

National Cancer Institute

\section{Source}

National Cancer Institute. PRMT5 wt Allele. NCI Thesaurus. Code C127856.

Human PRMT 5 wild-type allele is located in the vicinity of $14 q 11.2$ and is approximately 9 $\mathrm{kb}$ in length. This allele, which encodes protein arginine N-methyltransferase 5 protein, plays a role in arginine metabolism. 